\title{
Speaking for the Voiceless: Yvonne Vera's Characters and Social Conditions
}

\author{
Ifeyinwa J. Ogbazi* \\ DOI: http://dx.doi.org/10.4314/ujah.v12i2.5
}

\begin{abstract}
This paper focuses essentially on the characters we find in Yvonne Vera's four subsequent novels after Nehanda, namely: Without a Name, Under the Tongue, Butterfly Burning and The Stone Virgins. It is the objective of the paper to substantiate Vera's implied posture that the women of Zimbabwe, whose portraitures she presents to us, and who also she perceives as constituting the major voiceless members of their society, are the ultimate victims of both colonial experience and post-colonial tensions. In the course of pursuing the thesis that the bulk of the events that make up Zimbabwean history is synonymous with oppression and suffering of the women, the paper argues that these casualties of Zimbabwean political and social developments are genuinely handicapped and that is why the female characters especially usually end up not living fulfilled lives in as much as they have their set goals and dreams in life. The paper reveals that society-imposed structures and conditions account greatly for their many bizarre deeds, so that when all is considered, it is discovered that Vera wants us to absolve her female protagonists because society has sinned more against them than they have against it.
\end{abstract}

\section{Introduction}

When the West intruded into the African world in the later part of the 19th century, the colonizers did not walk, they did not run; instead, they rampaged and trampled on the African 
space. In addition, they distorted the people's culture, and to a greater and more devastating extent, they crushed the lives of the colonized peoples. The ensuing struggles that erupted in opposition to the partitioning of the continent in many African communities were fierce, excruciating, and profoundly damaging. Ever since then, nothing has remained the same. Anene and Brown give a comprehensive result of this unfortunate contact with the West thus:

Once accomplished, the partition altered the course of African history almost completely; Africa was forcibly jerked on to the stage of world history, carved up into new, often artificial units, which nevertheless form the African nations of today. Her people were placed in situations in which they were made by circumstances to adopt new concepts to African conditions, to digest the European idea of the state, to adopt the capitalist economic organization, rapid communications, and scientific technology and even to adopt French and English in order to be able to communicate with fellow Africans. Such changes amounted to a fundamental revolution in the economic, social and political life of Africa. (129-130)

Because of the centrality of this experience in the lives of the people, the varied social, political, and moral consequences of the colonial enterprise in the African continent, as well as the ever continuing experiences of people in the post colonies, have been consistently addressed by African postcolonial literary artists of which Yvonne Vera was one of them. Vera, dwelling on the Zimbabwean upheavals, exploits exhaustively, in her five novels, both the experiences of 
colonialism, the Zimbabwean Liberation Wars and post independence political events.

As chronicles of postcolonial fiction that explore the Zimbabwean experience, these novels have been particularly written out of the female experience. As an African feminist postcolonial writer, Vera portrays in great detail the dire consequences of the first and second Chimurenga. Chimurenga is a Shona word that means struggle. According Gunner, "The Zimbabwean Chimurenga was a guerilla war and it was in important ways a people's war with land and a sense of dispossession at the centre" (qtd in Jo Dandy 95). The novels are primarily her representations of the devastating impact of the emerging social forces on the lives of the people. For her, even when the toll of these historical events is more on the humans generally, women are worst victims essentially because the advent of colonization exacerbated the already injurious forms of subjugation that are incorporated in the African patriarchal system which, in the main, propagates and perpetuates inimical subtle types of silencing.

What is of primary interest in this paper is to explore the artist's portrayal of the significant features of modern consciousness which have accrued from colonial and post colonial anarchy, and which Vera has laid a heavy emphasis on in order to illustrate how the past events have accumulated to accentuate the stifling and dreadful circumstances of the present. In this respect, therefore, the paper examines her representations of the debilitating impact of these emergent social forces, analyzing the different ways the writer has exemplified how the ensuing convolutions, the rapid flux, the evolving structures of their society, coupled with the changing patterns of behaviour of modern city life impact particularly on the African female personality and contribute to the women's tragic experiences. 
It is Vera's belief that there are events, situations and attitudes that have precipitated the horrible and inhuman scenes which she depicts. As such, in different ways, she depicts the varied situations her characters grapple with and how the women contend with such constraints that have been imposed by social arrangements and events that include the patriarchal setup, the nationalist struggles and the conflicting demands emanating from the modern state. Invariably, she insists that it is society that has created a psychological disorder for her characters since the attendant social conditions conspire to provoke, for instance, the women's encounter with brutality as well as bring them to their various points of no return.

In order to illuminate better the odious experiences of the female victims of Zimbabwean history as well as enhance our understanding of the victimizers, and trying to comprehend their attitudes and deducing reasons for their various conducts and moral state, the male characters will, where necessary, be brought into perspective. This is also important because the writer wants us to accept that both the women and the men constitute the voiceless members of Zimbabwean society.

\section{Vera's Characters and Social Conditions}

In her subsequent novels after Nehanda, Vera consistently explores "how the self may be forged from the history of war and national emergence" (Wilson-Tagoe 2). In the first instance, Vera implicitly brings to our attention the background of her female characters in the four mentioned novels after Nehanda. We find that there are some similar characteristics that strike the reader. Mazvita in Without a Name has no parents. Her parents have been killed in the war. She is a loner, without family and without relations. The background of Phephelaphi in Butterfly Burning is 
shrouded in controversies. Her name has been generated from her background. She tells Fumbatha, "My mother named me Phephelaphi because she did not know where to seek refuge when I was born. She slept anywhere. She had no food in her stomach, but her child had to sleep under some shelter. She had bad times. "As soon as I was born her struggles began" (29/30). Phephelaphi is a name that depicts the struggles of mother and child - "...she said that Phephelaphi was the name she had now found for both of us. She had struggled" (30). At the age of six, Phephelaphi's mother changed her name from Sakhile when "she discovered that Makokoba had no time for a woman who was raising a child on her own..." (30). All the above reveal an indefinite and checkered background that contributes to Phephelaphi's continuous quarrelling with herself thus, "she argued with time. She argued with the memory of her mother. How could she have been her mother when they did not know each other's proper names?" (33).

The direct consequence of such a background that is premised on the absence of childhood is that it has contributed in creating an unstable personality for the character. Added to this, it has failed to create the natural bondage between mother and child. Not firmly rooted in the family, she has no strong foundation from which she can take her bearing in life. Vera continuously highlights this aspect of the vital missing link in the lives of many of her characters. It is in this respect that Shaw tells us that in her novels, "The mother-daughter connection brings pain, abandonment, infanticide, and abortion" (34). She goes further to expatiate on the calamitous consequence of the absence of childhood in the life of Phephelaphi in this way: "Childhood should offer a burden less, weightless body of clear perfection, presaging the death at the end of the novel, Phephelaphi never has a childhood and as a woman is denied, 
the butterfly's lightness of being. She achieves this with death" (35). This vacuum created at the early and crucial stage of her existence dogged her entire life until her disastrous end.

Deliwe also of Butterfly Burning lives alone in the city without any husband or any other relation while the two sisters of The Stone Virgins - Thenjiwe and Nonceba - have no parents. They are equally from a war-torn area. All of the women that we find in these novels are usually without shelter, and where they have any, it is usually a one-room apartment. They live alone and do not have concrete, decent jobs. Some are engaged in prostitution and they are also involved in the sale of liquor like Deliwe, a trade that contravenes societal laws. In sum, they are loners, solitary people who are either not married or they are divorced or they have lost their husbands (most probably in the war). They are all victims of circumstances especially when they have been violated in the past. Their past is replete with stories of violent experiences. It is these ugly experiences of their past that have made them loners; turned them into solitary travelers.

The women's joblessness and homelessness create fluid situations for them. They are, during the greater percentage of their lives restive and insecure and constantly on the move in search of employment and a better future. Because of the raging liberation wars in the rural places where they come from, they are often forcefully uprooted from the villages and thrown into the tide of events unprepared for, emotionally, psychologically and financially. The intense tension they are subjected to make it difficult for them to grapple with the harrowing pressures of their day-today existence. As they move in search of better conditions of living, especially in the process of their movements in trains, they become easy preys to men, and are often violated. They 
are also grossly assaulted by the men in tight, overcrowded township accommodations. They are frequently harassed and raped in war battered areas. Just as we see them in their constant movements, in likewise manner, they are in continuous turbulence mainly because the chaotic and disorderly environment gives leverage to the men to plunder and abuse them.

In Without a Name, Vera also uses the journey motif to illustrate the women's movement from rural to urban areas, thereby highlighting the "migration of people in all industrialized countries during the modern period, with its destructive effect on their traditional gender roles". This is essentially because the process of industrialization and urbanization worsened the attendant cultural crises that have erupted. This destruction of society impacts directly on the family. The family unit, with its traditional relationships and duties, has been greatly destabilized. The men are no longer committed to their prescribed roles in families. Equally, it is because of the new development whereby the family as a social unit has broken down that has given rise to the women not being protected any longer. Thus, they are all highly exposed to the vagaries of their society. Shaw points out that "Vera's imagination is not bound by African tradition: women's identities are not grounded in their generative powers; men do not protect; the community does not shelter the individual, and the ancestors do not bless their descendants" (36).

The concept of motherhood has also been eroded in many ways as is illustrated with Mazvita's unwillingness to name her baby and her subsequent killing of the child. She knows full well that the option that is open to her, considering her circumstances, is to do away with the burden of her baby, an extreme act described by Ruth Lavelle as, "the most soul-destroying act that a woman can..." (III). 
Pointedly, her action is hinged on the fact that the child will bind her to her past, a past she has escaped from and which she will like to put behind her perpetually. Her killing the child is her own way of resistance, resisting her being forced back to a past that impedes her future survival. Lavelle explains:

Mazvita cannot name the child because she does not love it; to name it would be to accept it. The baby prevents Mazvita from moving away from the pain of her past - it is a barrier between what she is and what she can become. This is why she must destroy it. 'The child brought her such powerlessness she could hardly move forward'. $(86)-(112)$

In this respect also, Bull-Christiansen points out: "The protagonist Mazvita feels betrayed by nature and the spirits which inhabit it, and in an act of transference she wipes the memory of the guerrilla soldier who has raped her in the bush from her mind and replaces it with the moment itself: 'Hate required a face against which it could flung but searching for the face was futile' (Without, 36) (25). Alas, but expectedly, she cannot find a replacement that will banish the memory of this much despised, so-called liberator who has impeded on her life.

When we critically consider Mazvita and Phephelaphi's actions, we have to admit that they are the cropping up of new relationships that are antithetical to what was obtainable in the pre-colonial traditional African society where the arrival of a baby brought joy and fulfillment. It used to be a welcome event, accepted by the family and the entire community. In the post colonial Zimbabwean society, a child is seldom welcome in the family. It is no longer a 
cherished gift but a burden that can be an impediment to the future progress of the mother.

This is one of the different ways through which Vera depicts how the cherished and highly valued motherhood is contradicted. Mazvita's and Phephelaphi's actions violate the traditional notion of motherhood that embodies maternal love, maternal care and maternal obligations. It is therefore irksome as we watch, for instance, the milk, the precious lifegiving maternal substance, seeping from the breast of Mazvita after she has done away with her baby. In this instance, the breast milk becomes a wasteful life giving product and thus, no longer feeds the young that it ought to. It is a clear exemplification of one of the awful situations/conditions that colonialism has precipitated. Vera consistently decries what colonial and postcolonial tensions have done to motherhood. For her, the essence of motherhood to the woman and to the community has been profoundly bastardized.

Vera also brings to our notice the repudiation of female bonding that was a vital aspect of female/female relationship in the traditional set-up. Phephelaphi's rejection by her male lover, Fumbatha, is compounded by Deliwe's betrayal. Before now, Phephelaphi's acquaintance with Deliwe was a relationship that so much excited and inspired the former. She found herself attracted to this relationship and drawn intimately into it. She found an inner peace in it, and was hopeful that it would assist her at least to find her bearing within the distorted space. She desired to take a cue from Deliwe. She had hoped that her influence would bring to the surface something positive that is latent in her, would have a predominant positive impact. She was convinced that through her, she could comprehend her world better. But it turned out to be another broken dream. 
Ordinarily, the common circumstances of these two characters are expected to constitute a strong bonding agent. Woman/woman relationship, particularly in such an environment, is necessary and imperative since as a source of bonding, it should be an avenue for solidarity. Such sisterhood helps in ameliorating their sufferings. It, as well, helps them create an alternative space as a source of survival. Ogundipe-Leslie upholds that "solidarity among women offers a safety net and a breath of fresh air in a suffocating, constraining environment" (19). Unfortunately, in this case, it is difficult to foster such solidarity because of the prevailing conditions.

The motives that underlay Deliwe betraying the trust a young woman like Phephelaphi reposes on her can be defended because she has to survive; she has to make a living in the face of the grueling city hardship. Iniobong I.Uko admits that,

The realities in post colonial Africa compel different people to device various strategies for survival. In some African environments, the rigid and intimidating impact of colonialism and callous and selfish orientation of neocolonialism result in the asphyxiating poverty and excruciating suffering of the common people [particularly women and children].(142)

In her own pragmatic way then, Deliwe practices prostitution as her survival strategy. In the face of the existing living problems she has to contend with on a daily basis, she probably does not have the room to weigh the moral consequences of her actions, especially on the issue of having an affair with Fumbatha. Like many other women of her society, through their struggles, they aspire for an illusive 
freedom, a freedom that coerces them into commercial sex work at the expense of their integrity and respectability; the freedom that boost their ego in their defiance against moral principles and ethical conduct (Uko 154).

Vera presents the women as indices "to the worsening conditions of modernity in the postcolonial context." (Udumukwu 380). Bull-Christiansen also points out that "modernism as well as traditionalism is viewed from a critical perspective in Vera's descriptions of the war-torn landscapes and cityscapes in [these] novels." He goes on to describe the city as a place that "does not offer freedom; on the contrary, she experiences emotional decay and spiritual poverty. The city is a place which lacks memory. Vera's description of the city can be termed an 'urban dystopia' (25). Such a city that is violence prone, highly volatile and full of uncertainties, not only makes stiff demands on the women but on the people generally. The township spaces are highly confined, lonely, restricted and are violated spaces where mundane practices debase and immoral actions are regular features. The dwellers' pursuits are demeaning and condescending. It is a vacuous space - physically, spiritually, emotionally and morally. Pointedly, there is grave disorder within the social order. These are among the reasons why survival in the city like Makokoba is difficult for women like Phephelaphi in Butterfly Burning. There is no way she can grapple with the two major tasks of nursing a baby and pursuing a nursing career.

It is in light of the fore-going that Vera continuously draws correspondences between the immoral actions of the men and the prevailing sordid situations of city life. She exemplifies how their actions are part of the societal malaise. The climax of the dehumanizing tendency of the social condition instituted by the colonial project and postcolonial policies and events is well depicted by Vera in Under the 
Tongue. The novel, just like the other three, is a thesis that is based on life as it is lived in the city. The society has turned into a place where the men no longer respect filial relationships and this mainly accounts for Zhizha's violation by her father.

Men like Nyenyedzi, Joel and Fumbatha cannot also afford the extra responsibility of caring for mother and child. For this major reason, they seek an escape route, and that route is venting their anguish on the women. When we take the circumstances of the men into consideration, the bitter truth is that they have no honour left in them to cherish and protect, having been so much deeply hurt, humiliated and brutalized. In their relationship with the women, beneath the external expression of sexual desires, there is an inner wound that will not be easy to heal or erase, not even by the romantic gestures of the young women, "with their immaculate thighs and tender voices and unblemished skin, they will make a new sun rise and set so that yesterday is forgotten" (The Stone Virgins, 50). Nothing is sufficient or possesses the potency to fill the loneliness they feel right inside their beings.

Bull-Christiansen, in the elaborate quotation below, explains the male character Sibaso's perception of his rape and murder of Thenjiwe and rape of Nonceba in The Stone Virgins thus:

The way in which Sibaso has violated Thenjiwe and Nonceba is from his point of view described as a 'natural' pattern of action that is a consequence of the war. During the war Sibaso has lost a determining part of his being, his name, and he has become a lifeless envoy of desecration and violation of kindness. Seen in this way, his murder of Thenjiwe and rape of 
Nonceba appear as the result of a world that is distorted and in chaos. During the war, he has been taught to behave in a certain way which he repeats after the war. He is a dissident, hunted by the government forces and feared by the civilians. He is in hiding and he is attempting to restore his world-view which has been irrevocably distorted both during the war and in the following social chaos of the Gukurahundi. (94)

It will be right to say that Bull-Christiansen here encapsulates the collective consciousness of the men. His statement, no doubt, is very revealing as it succinctly accounts for the reasons for the mindset of the majority of them. Just as he has highlighted, there is an inimical behavioural disposition that has arisen from the patriarchal system, their participation in the war, and their numerous disappointments in the eventual turn of events within the postcolonial order.

Phephelaphi is among the category of young unexposed women who fail to interpret properly the moral climate of the present dispensation. We are told in The Stone Virgins that the women who have gone to the war, and now more enlightened, have to blame "...the young women who think freedom can be held in the hand, cupped like water, sipped like destinies. Who think that water can wash clean any wound and banish scars as dry as Kwakhe sand [...] they mistake the porous sands of Nyande for the substance of their laughter, their reckless joys, their gifts" (50). Phephelaphi grossly underestimates the impact of the war on her lover. She fails to take into cognizance, probably because she has loved and trusted so much, her mind is beclouded and for this reason, she cannot make an objective appraisal of the extent the historical events have affected the personalities of the 
men, their outlook to life, coupled with the quality of their moral behaviour. The men's toils and sacrifice are neither appreciated nor duly rewarded because, "The work is not their own: It is summoned. The time is not theirs: it is seized. The ordeal is their own. They work again and again, and in unguarded moments of hunger and surprise, they mistake their fate for fortune" (5).

Even after independence, the men are still grappling with this typical situation that illustrates the continuation of colonial oppression, an instance where colonial power still exerts a strangulating and even more enduring hold on the people, in this case, on the men - a situation that constitutes "an even more potent power in their absence" (Nwankwo, 'To Trans-emote,' 52). Vera projects the view that it is the men's allegiance to their modern society that obliterates their traditional African responsibilities to their families especially to their wives and children. For her then, no society can progress, thrive, in the absence of a stable family.

There is the absence of reciprocal love in the men's relationships with the women. There is misconception of motives and betrayals of mutual trusts. Their love relationships are characterized by suspicion and tension. The intensity and fervour of sexual intimacies do not correspond with true emotional commitment. Thenjiwe of The Stone Virgins makes love to her lover, "with panic and envy, as though he is an unreliable lover" [36]. That he is in actual fact. In all the men's relationship with the women, such canal intimacies offer nothing in ameliorating both the problems of their personal lives and that of the general society; in fact no private, social or political problems are solved. Obviously, there are clear indications of lack of satisfaction and fulfillment as the inner pains persist and the deep hurt continues to linger. Vera persistently highlights the various reasons that may account for the "uncontrollable irresistible 
force" of the male characters' libido [Osafisan 4]. The major one has to do with space. Space features predominantly in these four novels and equally plays a significant role in the lives of the characters. In them, she evokes the very restricting, inhibiting and stultifying characteristics of the constraining places as spatial limits. She reveals extensively the tight accommodation in the cities which subjects the characters to live lives that are very confining. Love affairs are "cocooned love relationships" like that between Fumbatha and Phephelaphi that is "ultimately, [....]a oneroomed love which implicated them all, and there was nothing any of them could pretend was new or painless about the situation and its ambivalent surprises"(Butterfly 36). Lunga expatiates on this condition thus:

Makokoba offers restricted physical movement. Thin walls separate the tiny one-roomed shacks, making it difficult to hide. Almost everybody knows each other's secrets, thus creating the feeling of being forever watched. Nothing happens that is outside view. Besides being curtailed by physical boundaries and the smallness of Makokoba, movement is also restricted by the perpetual gaze of neighbours and the surveillance of the colonial masters. (192193)

These are the conditions that the characters are compelled to contend with in their daily lives. It is such tight living conditions that trigger off sadistic behaviour in the men and precipitate the bizarre actions like that of Zhizha's father. They invariably become perpetrators of violence. In addition, this situation makes it difficult for the women to be able to checkmate or resist the force of the male libido earlier highlighted. 
The issue of patriarchy comes in to aid such conditions for the men. The internal power structure as instituted in the traditional culture in African societies makes a lot of allowance for the male to freely subjugate and take advantage of the women. In the family, there is the brutal control between the man and woman, as well as between the father and the daughter. With regard to Zhizha's experience in Under the Tongue, Eldred J. Jones highlights the critical point that, "Many of the treatments of childhood have exposed a grim reality of cruelty, harshness, parental [particularly paternal] geocentricism and extraordinary bruising of the vulnerable child psyche"(7). The most traumatic aspect of this horror is that the child is not allowed to speak out because of the prevailing culture of silence that has been entrenched strongly within African patriarchy. BullChristiansen informs us: "Vera[....] uses the child's perspectives in Under The Tongue [in order to focus] on the child's experience of the liberation war and life in the townships that were not directly part of the war but still were affected by it." (26)

Vera abhors this loss of speech. She without equivocation condemns the state of being voiceless because for her, survival is in the mouth. Redemption can only come from an individual's ability to speak out. She believes that men's suppression of the female speech has heightened the suffering of women and is, in the main, what makes the African patriarchal system intrinsically flawed.

In many ways, Vera tries to portray the distinction between the exterior and interior aspects of the female characters' lives. Within their inner selves, they are active, stable, ambitious, and strong-willed and focused. They are filled with motivations and are obsessed to pursue a cause in 
life. They possess great potentials and inner power. They have aspirations and yearnings. When left to perform, they are ingenious and creative. However, in opposition to this vibrant interior, their exterior selves have been grossly impacted upon. Their bodies have been depleted, worn-out and abused. In these novels, it is the state of their bodies that constitutes the stumbling blocks in their lives. What entails the dilemma for each of these characters borders mainly on the quest for personal improvement, the desire to forge an identity. They make desperate efforts to create their own future, to fashion out a different form of life.

Their proactive nature urges them towards selffulfillment. Mazvita wants to progress in life but her pregnancy and eventually, her new born child - the product of her rape - impedes this desire. Phephelaphi's pregnancies stand between her and her desire to train as a professional nurse. We are told that, "it was two weeks after she had been accepted to train as a nurse that Phephelaphi realized that she was pregnant. She was a June intake, the admission papers said...." (99) Her anxieties that culminated in her tragic end are borne out of the many uncertainties of life surrounding her. Zhizha's heinous violation by her father destroys her today and tomorrow. Thenjiwe and Nonceba's traumatic experiences are stultifiers to the attainment of their goals in life.

The women are aware that they need to acquire so much knowledge through education that they need to be enlightened in order to be able to free themselves from the shackles which society has created for them. Daryl Mcgowan Tress buttresses the point that, "Without the possibility of a coherent self, liberation becomes impossible....(197). James Wolfensohn is also of the view that, "education is central to 
ones ability to respond to the opportunities that development presents...." (41)

However, from Vera's representations, we discover that, as if in the form of opposing dialectics, while one aspect of women's beings, their inner selves, makes effort to propel them to heights, the burden of their bodies pulls them down to the pit, oftentimes, to points no return. They end up not living fulfilled lives. Essentially, it is their failure to succeed in achieving their aims and aspirations in life that constitute the core of the ultimate tragic consequences of their end. Ranka Primorac agrees that "Vera's characters have inner lives which do not undergo change; their minds are lively, mature and free from the very out set of their stories. It is their bodies that they do not fully posses, and therein lie their tragedies" (xiv).

This can be illustrated with the protagonist, Mazvita. Vera depicts her subconscious but very obvious desires in Without a Name. She represents the conflicting nature of this inner yearning and the opposing pressure accruing from the society. In spite of the negative social forces, the character's resolute intentions are discernible and we are allowed to follow her growth as she encounters life-building experiences. Amidst the turbulence, instability and the uncertainties, she, like other female characters like Phephelaphi, Deliwe and Nonceba, dares to move forward, to risk it, to venture, in order to surmount the obstacles of their lives. Propelled by their rebellious spirits, they make continuous efforts to seek a new identity. Shaw highlights the point: "In all of Vera's novels, protagonists seek both connection and freedom. Her novels are themselves meditations on the various ways in which connection is lost and achieved and freedom sought after and denied. Vera embraces the contradictions" (35). In such ways, Vera continues to suggest that the new world of modernism 
harbours potentials that are "portentous and destructive of private values and aspirations" (Nwahunanya 48). Gikandi also reminds us that in a postcolonial situation, "---the nation is not the manifestation of a common interest but a repressor of desires..." (qtd in Vambe,134).

In continuation of her cataloging the huge sacrifices of her female characters, it is in The Stone Virgins that Vera reveals to us that the women of Zimbabwe, who she brands the Stone Virgins, right from the very beginning, in the traditional religion, have made incalculable sacrifices. The women in the cave carvings who Sibaso discovered as he ironically makes a spiritual retreat to the caves while seeking refuge and solace, points to a sacrifice that is historical. They have been offered as sacrifices in the course of the burial of a king as Vera informs us thus:

They are the virgins who walk into their own graves before the burial of a king. They die untouched. Their ecstasy is in the afterlife [ ]. Sacrifice means the loss of life, of lives, so that one may be saved. The life of rulers is served not saved $[\ldots]$. The female figures painted on this rock, the virgins, form a circle near the burial site, waiting for the ceremonies of their own burial. (95)

The essence of this historical information is that Vera uses it to buttress her assertion that from the onset, from time immemorial, women have been making sacrifices of great magnitude especially with respect to their not being allowed to live a life of their own. They have often lived, only specifically, to serve the interest, satisfy the pleasures of the kings of old, and never in any way have they lived to fulfill their own desires or pursue their aspirations in life. They are 
perceived by the men to be 'the stone virgins'-virgins of the stone country, Zimbabwe, and as it is characteristic of stone, they are expected to be without feelings, without emotions and without desires. Because of this unfeeling nature of theirs, they ought to be toyed with, manipulated according to the whims and caprices of the men. It is the transference of this notion that Vera depicts in this novel (and in other novels). Hence, Bull-Christiansen rightly observes:

To Sibaso, Thenjiwe and Nonceba appear to be 'The Stone Virgins.' His description of the stone virgins in the shrine in the Gulati Hills creates a connection between vera's representation of Nehanda, are depicted as the keepers of the time. Sibaso's interpretation of the cave painting and his likening of Thenjiwe and Nonceba to the stone virgins of the shrine forms a re-enactment of the virgin sacrifice in the defining act in the novel: the murder and rape of Thenjiwe and rape of Nonceba. (96)

Other protagonists have made equally varied daring sacrifices, they have compromised a lot in their bid to gain personal freedom. Expressing her views on Mazvita's own experience, Ruth Lavelle notes, "realizing the need to salvage her freedom and heal the wounds of the past, Mazvita commits infanticide [---] Mazvita's sense of self was shattered after the rape, since then, until she returned home, she was without a name (110).

We also still remember Zhizha's destruction by her father, and Phephelaphi's self abortion and eventual immolation. The question still remains: In all these, how do we judge these female characters? When we consider all that the women go through, in judging their actions, that of the 
protagonists particularly, we should first of all bring into perspective their inner yearnings. Their quest for self improvement, no doubt, implies that they are not satisfied with their present positions. In many ways, Vera draws our attention to the unhealthy conditions of living these characters are subjected to by pitching them against the current of the society, immersing them right into societal sordidness. That they seek alternative and better ways of life is invariably their own form of revolt against existing situations. They consistently crave to be free, and to crush an inner longing in an individual, to shatter an intensely desired goal, tantamount to destroying that person's entire world. Moreover, it is important we interpret their actions essentially not only as accruing from environmental influences- the moral attitudes that surround them, but very significantly, we should bring into perspective the wrongs that have been done to them.

It is revealed that Vera's protagonists are innocent sufferers. They are harmless, defenseless and helpless beings. They have inherited the chaos of their society and they undergo terrible experiences because of the ways the societal set-up impacts on them. They are scape-goats who have been subjected to so much suffering, not because of their shortcomings or failures in life, or their negative innate qualities; or still, not because of their error of judgment, but primarily because their society has imposed these sufferings on them.

When we make an objective appraisal of their lives, we observe that they have been violated severally. They have been betrayed, rejected and humiliated. They are surrounded by unfriendly people who are uncaring and indifferent to their plights. They are not loved in the real sense of the word since love entails caring and reciprocity. Their love gestures, especially towards the men, have not been reciprocated. 
They go through travails in order to come to terms with their wounded and broken selves. Believing that their society and the people have exploited them and cheated on them, their feelings of indignation propels them to act in dire ways. It is their expression of anger against their society that makes them react in such extreme ways that we see.

Expectedly, the female characters rebellion does not redeem them because they end up having catastrophic consequences. They do not come out victorious since they are destroyed in the course of their grappling with the prevailing societal forces that constitute the terror of their lives. We should accept that their actions stem principally from the "catatonia that follows a heart break" (Osafisan 44). Typical examples can be illustrated with the cases of Mazvita and Phephelaphi whose types of psychic symptoms show evidence of schizophrenic disorder. Their extreme reactions are, no doubt, attributable to this mental state. In substantiating, in a way, the desperate actions of the women, Francoise Lionette highlights the fact that

... whereas murder is generally considered to be a crime of the individual against society it (can be) present as a symptom of society's crime against the female individual. Struggle for the control of their own bodies determines the ultimate act of resistance and survival. (209)

In essence, the society has sinned most against them more than they have sinned against it. Their only sin is that they seek to be fulfilled; they strive to achieve their dreams, to attain their aspirations in life. They strive also for identification. They struggle to have a foothold in their society- to be recognized, appreciated and rewarded. 
In light of the foregoing, Vera wouldn't want us to condemn her protagonists. Instead, she expects us to empathize with them. She wants us to feel for them since they are products, as well as victims of their society's disharmony. Their sufferings and actions are illustrative of, and typify the existing societal disorder.

\section{Conclusion}

As vehicles of the authors ideas, the characters that are depicted in the novels of Yvonne Vera used in this study dramatize essentially, the mal-functional state of the Zimbabwean nation. Through them Vera gives her message concerning the country by exemplifying in various ways how the crises in their lives are reflections of the sordid state of affairs of the country.

The author connects the fatalistic experiences of her characters, depicting them as the resultant impact of colonial, oppressive, debilitating structures and the concomitant postcolonial tensions and upheavals. While highlighting particularly the female experiences, her primary interest is to portray how these are the consequences accruing from the colonial enterprise. She portrays how the emergent urban settings impact on them, violating both their bodies and their rights and how consequently, the African female personality came to loose the essence of her being.

Vera is of the view that even when the toll of colonialism is more on humans, the women are worst victims essentially because it exacerbated the already injurious forms that are incorporated within the African traditional patriarchal set-up. She also insists that an overt grave injustice has been done to them, an injustice that no one wants to acknowledge and address. This injustice stems mainly from the fact that their tremendous sacrifices to the nation have neither been commended nor rewarded. 
It is in pursuant of this that she courageously confronts taboos, unravels numerous aspects of hitherto hidden, sordid, excruciating experiences of the women. As a post colonial African female writer, the vital message that is encapsulated in the totality of Vera's representations is embodied in Khombe Mangwanda's poignant statement thus:

Vera is concerned about the impact of colonial invasions on African people and traditional ways of life [---] \{she\} identifies the coming of the Europeans as a symbol of death. In her text, she highlights the undesirability of the European presence in the land because of the pernicious effect "unknown customs" might have on indigenous people. (145)

It is in view of the multiple grave situations that colonialism has precipitated that Vera wants her readers to come to the conclusion that socio-economic circumstances have tremendous impact on human behaviour. Being a major contributing source, she maintains that these social conditions definitely brewed and nourished the evil that are portrayed in the narratives.

It is essentially in this respect that she calls on all Africans and African nations to critically examine postcolonial policies inherited and continued by many African countries, even after independence. She adduces that there are inherent dangers in upturning a people's way of life through the introduction of foreign policies. Hence, she admonishes her people for their inability to identify and uproot all oppressive colonial structures, no matter in whatever guise they present themselves.

Finally, if we have to borrow Udumukwu's view (though in a different context) "if by modernity we mean a 
conscious effort to transforming lives as a consequence of nation-formation [---]," Vera is advocating, through her depictions, that her people have failed in their bid to establish a modern progressive state since the nation's transformation into modernity has not brought a positive transformation of the people's lives" [377]. Ultimately, as Vera's novels are primarily critiques of colonialism, her representations can be deduced also to stand for the rape of the Zimbabwean, and by extension, the entire African space.

\section{References}

Anene, Joseph C. \& Godfrey Brown. Eds. Africa in the Nineteenth and Twentieth Centuries. Ibadan: U of I Press \& Nelson, 1966.

Bull-Christiansen, Lene. Tales of the Nation: Feminist Nationalism or Patriotic History? Defining National History and Identity in Zimbabwe. Sweden: Nordisk, 2004.

Gikandi, Simon. "African Literature and the Colonial Factor." African Literature:An Anthropology of Criticism and Theory. Eds. Tejumola Olaniyan \& Ato Quayson. Blackwell, 2007.

Gunner, Liz. 'Power, Popular Consciousness and the Fiction of War: Hove's Bones and Chinodya's Harvest of Thorns', African Language and Cultures, 4.1, 1991. Jones, Eldred D. "Childhood Before \& After Birth." African Literature Today 21 (1998): 1-8.

Lavelle, Ruth. "Without a Name: Reclaiming That Which Has Been Taken.” Muponde \& Maodzwa-Taruvinga. 109-114.

Lionnet, F. Geographies of Pain. The Politics of (Mothering, Womanhood, Identity and Resistance in African 
Literature. Ed. Obioma Nnaemeka. London/New York: Routledge, 1997: 205-227.

Lunga, Violet Bridget. "Between the Pause and the Waiting:

The Struggle Against Time in Yvonne Vera's Butterfly

Burning. Muponde and Maodzwa-Taruvinga: 191-202.

Magwanda, Khombe. "Re-mapping the Colonial Space:

Yvonne Vera's Nehanda." Muponde and Maodzwa-

Taruvinga: 141-154.

Nwahunanya, Chinyere. Tragedy in the Anglophone West

African Novel. Owerri: Springfield Pub. Ltd., 2003.

Nwankwo, Chimalum. "Globalization, Literature and

Languages: The All-Knowing Subject and the

Insentient Object." CALEL. Vol. 4 (May, 2006): 32-42.

"To Trans-emote a Cosmos Yvonne Vera's Holistic

Feminist Vision in Butterfly Burning." New Women's

Writing in African Literature. Ed. Ernest N. Emenyonu.

New Jersey. Africa World P. 2004: 43-54.

Ogundipe-Leslie, Molara. Re-Creating Ourselves: African

Women \& Critical Transformations. Trenton, N.J.:

Africa World P. 1994.

Osafisan, Femi. Literature and the Pressures of Freedom:

Essays, Speeches and Songs. Lagos: Concept, 2001.

Primorac, Ranka. "Iron Butterflies: Notes on Yvonne Vera's

Butterfly Burning." Muponde and Maodzwa-Taruvinga:

101-107.

Shaw, Carolyn Martin. "A Woman Speaks of River:

Generation and Sexuality in Yvonne Vera's Novels."

Muponde and Maodzwa-Taruvinga: 83-91.

Tress, Daryl Mcgowan. "Comment on Flax's

'Postmodernism and Gender Relaions in Feminis

Theory." SIGNS: Journal of Women in Culture and

Sociey. Vol. 14. No. 1. (1988): 196-203. 
Udumukwu, Onyemaechi. "Borderlines of the Nation Space:

Land and Marginality in Meja Mwangi's Striving for the Wind." Koroye \& Anyadike. (2004): 372-387.

Uko, Iniobong I. "Female Prostitution as Metaphor for

Survival in Cyprian Ekwensi's Jagua Nana and Nawal

El Saadawi's Woman at Point Zero." CALEL, Volume IV, May, (2006): 142-155.

Wilson Tangoe Nana. "History, Gender and the Problem of Representation in the Novels of Yvonne Vera." Muponde and Maodzwa-Taruvinga: 155-178.

Wolfensohn, James D. Engineering Development Through Gender Equality in Rights, Resources and Voice. The World Bank Policy Research Report, 2001.

Dr. Ifeyinwa J. Ogbazi is of the Department of English Language and Literature, Nnamdi Azikiwe University, Awka 